\title{
Assessing the Risk of Stewart's Disease of Corn Through Improved Knowledge of the Role of the Corn Flea Beetle Vector
}

\author{
Paul D. Esker and Forrest W. Nutter, Jr.
}

Department of Plant Pathology, Iowa State University, Ames 50010.

Accepted for publication 12 February 2002.

Stewart's disease of corn, caused by the bacterium Pantoea stewartii, is an economically important disease of sweet and seed corn. Significant losses can occur in sweet corn $(6,10)$, while zero-tolerance phytosanitary regulations limit the ability to export U.S. seed corn to other countries when seed corn originates from fields where Stewart's disease has been found (5). This is especially important because the prevalence of Stewart's disease has increased exponentially between 1995 and 1999 (Fig. 1) (5).

An extremely important component of the management of this disease involves controlling the corn flea beetle vector (Chaetocnema pulicaria) (2). To improve management of the corn flea beetle, more knowledge is needed regarding its population dynamics during the growing season. Adams and Los (1) developed a late-season degree-day model for managing Stewart's disease by applying foliar insecticides to control corn flea beetles in Connecticut. In the Midwest Corn Belt, however, there is a lack of knowledge regarding the exact number and seasonality of corn flea beetle generations that occur each season.

Another important risk factor that has not been adequately addressed concerns the population dynamics of $P$. stewartii-infested corn flea beetle populations within and among seasons. Roberts (8), Elliot and Poos (2), and Rand and Cash (7) have all tested corn flea beetles for the presence of $P$. stewartii at single points in time during the growing season by isolating the pathogen, but the monitoring of the temporal dynamics of infested corn flea beetle populations has not been attempted.

In order to improve management recommendations to reduce corn flea beetle populations, it is first necessary to improve our understanding of the Stewart's disease pathosystem. Three objectives were identified. The first was to use geographic information systems (GIS) to predict the seasonal and site-specific risk of Stewart's disease in the Midwest Corn Belt. The second was to obtain spatial and temporal information regarding the population dynamics of $C$. pulicaria using yellow sticky cards and sweep nets, and the third was to obtain temporal information regarding the population dynamics of $C$. pulicaria infested with $P$. stewartii using enzyme-linked immunosorbent assay (ELISA).

\section{MATERIALS AND METHODS}

Stewart's disease prediction maps were generated using ArcView GIS software (ESRI, Redlands, CA). Using the Iowa State Stewart's disease risk model, the number of months (December, January, and February) that exceeded the average monthly

Corresponding author: F. W. Nutter, Jr.; E-mail address: fwn@iastate.edu

Publication no. P-2002-0319-010

(C) 2002 The American Phytopathological Society temperature threshold of $-4.4^{\circ} \mathrm{C}$ was determined (4). This model was used to give a predicted risk for Stewart's disease for each county in Iowa. Zero months above $-4.4^{\circ} \mathrm{C}$ indicated a negligible risk for Stewart's disease, 1 month indicated a low risk, 2 months denoted a moderate to high risk, and 3 months denoted a high risk $(4,5)$.

To address objective two, yellow sticky cards and quantitative sweep netting were employed during the 1999 and 2000 growing seasons. Sticky card traps were placed in transects originating from grass borders and nongrass borders into each cornfield at intervals of $0,3,6,9$, and $18 \mathrm{~m}$ from each border. Sticky cards were changed weekly, and the mean number of corn flea beetles per sticky card was determined. Sweep netting was also performed at six locations in Iowa during 1999 and 2000. Each replication consisted of 10 sweeps per replication that were obtained weekly. Each replication consisted of a 6-m linear transect taken from the grass borders each week until corn reached the V5 growth stage. After the V5 growth stage of corn, 6-m linear transects were taken weekly from each cornfield until postsenescence. In 2000, a second set of 10 replications was taken from the grass border beginning in the middle of July and continuing weekly until corn flea beetles were no longer observed in the grass borders. The mean number of corn flea beetles per 10 sweeps (per replication) was determined. Both the yellow sticky card and sweep netting data were then used to elucidate the number and seasonality of corn flea beetle generations in Iowa (P. D. Esker, J. Obrycki, and F. W. Nutter, Jr., unpublished data).

Using individual corn flea beetles collected in objective two, ELISA was used to quantify the proportion of $P$. stewartii-infested corn flea beetles in objective three (P. D. Esker and F. W. Nutter, Jr., unpublished data). The ELISA procedure used was originally developed for seed corn (3) and was modified for use in testing individual corn flea beetles (P. D. Esker and F. W. Nutter, Jr., unpublished data). Individual corn flea beetles were ground in a phosphate buffer and tested with a compound direct, peroxidase $(490 \mathrm{~nm})$ labeled ELISA (Agdia Inc., Elkhart, IN). The binomial probability distribution was used to analyze statistically the proportion of corn flea beetles infested with P. stewartii (9).

\section{RESULTS}

The predicted risk based on the Iowa State risk model for Stewart's disease was moderate to high in 1999 and moderate to high to high in 2000 (Fig. 2). Prevalence of Stewart's disease in 1999 was $57.9 \%$ (762 fields out of 1,317 fields). Of the 1,304 fields inspected in 2000, 756 were found to have Stewart's disease $(58.0 \%)$. This was the sixth consecutive year of high prevalence in Iowa and second consecutive season of prevalence greater than $50 \%$ prevalence. 
Based upon the analysis of yellow sticky cards and sweep netting data, an overwintering and first and second generations of corn flea beetles occurred in Iowa in both 1999 and 2000 (Fig. 3). These generations occurred between middle April into early June, middle to late June through all of July, and from early August through September, respectively. Corn flea beetles were still found in grass borders throughout Iowa until early to middle November.

It is important to note that corn flea beetles were found 2 weeks earlier in 2000 compared with the 1999 growing season, and corn flea beetle populations were much higher overall in 2000 (44.90 \pm 7.89 corn flea beetles per 10 sweeps in 2000 versus $18.10 \pm 1.67$ in 1999). The higher population in 2000 adversely affected many fields in Iowa, requiring replanting of entire fields in southern Iowa due to Stewart's disease and insect feeding.

Corn flea beetles collected in the late fall of 1998 revealed that $0.044 \pm 0.031$ of the corn flea beetles tested were infested with $P$. stewartii at Chariton and $0.190 \pm 0.086$ were infested at Sutherland. For the first sampling date in the spring of 1999, the proportion of infested corn flea beetles in the overwintering generation

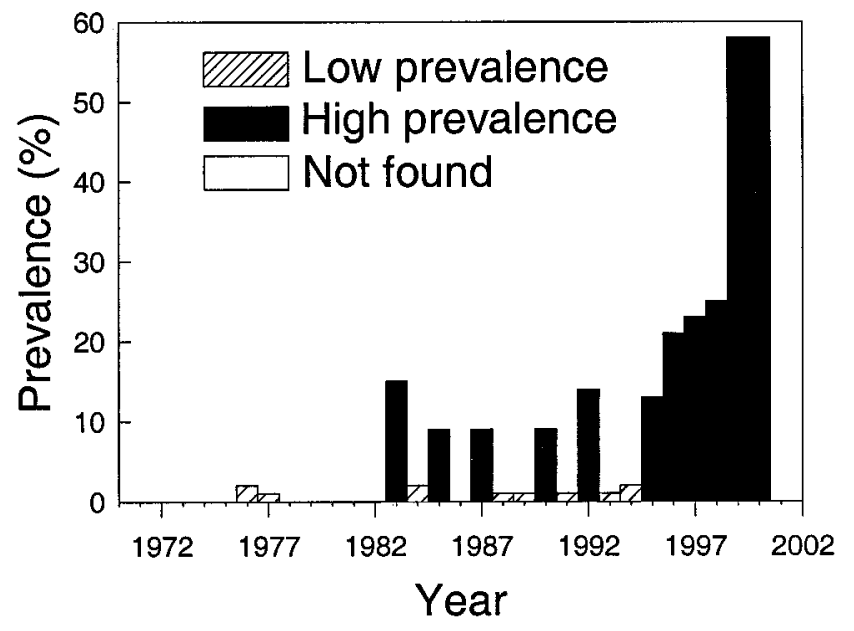

Fig. 1. Prevalence of Stewart's disease of seed corn in Iowa, 1972 to 2000.
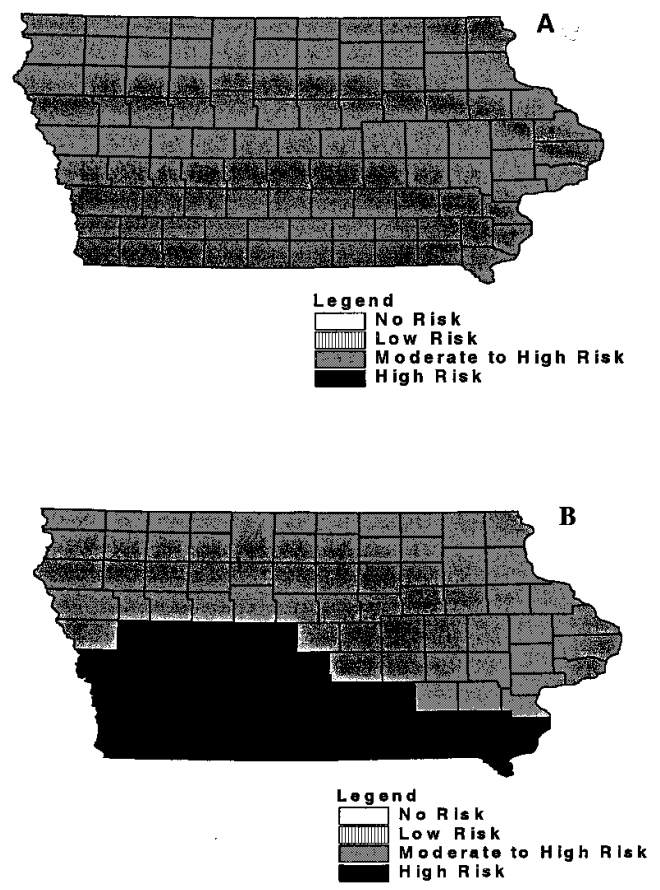

Fig. 2. Predicted risk of Stewart's disease in Iowa in A, 1999 and B, 2000. was $0.100 \pm 0.067$ at Ames, $0.114 \pm 0.048$ at Chariton, and $0.111 \pm$ 0.047 at Crawfordsville.

The proportion of $P$. stewartii-infested beetles fluctuated over time along with the population dynamics of the corn flea beetle populations. The proportion of $P$. stewartii-infested corn flea beetles ranged from $0.043 \pm 0.043$ (Sutherland) to $0.856 \pm 0.037$ (Chariton), with the highest observed proportions in early to late August (second generation) at all six locations.

Going into winter dormancy (fall 1999), the proportion of $P$. stewartii-infested corn flea beetles ranged from $0.200 \pm 0.034$ (Crawfordsville) to $0.733 \pm 0.047$ (Chariton). Proportions at the other locations were $0.433 \pm 0.052$ (Ames), $0.227 \pm 0.089$ (Kanawha), $0.239 \pm 0.045$ (Nashua), and $0.241 \pm 0.040$ (Sutherland). The proportions of corn flea beetles infested in the early spring of 2000 were $0.156 \pm 0.038$ (Ames), $0.300 \pm 0.048$ (Chariton), $0.089 \pm 0.042$ (Nashua), $0.170 \pm 0.032$ (Crawfordsville), $0.080 \pm 0.054$ (Kanawha), and $0.136 \pm 0.073$ (Sutherland).

Based on ELISA, the proportion of $P$. stewartii-infested corn flea beetles during the 2000 growing season ranged from $0.078 \pm$ 0.028 (Ames and Crawfordsville) to $0.533 \pm 0.074$ (Crawfordsville). Similar to 1999 , the highest observed proportions of infested corn flea beetles occurred during the month of August.

Going into winter dormancy (fall 2000), the proportion of $P$. stewartii-infested corn flea beetles ranged from $0.083 \pm 0.056$ (Chariton) to $0.200 \pm 0.042$ (Nashua). The other locations had proportions of infested corn flea beetles of $0.189 \pm 0.041$ (Ames), $0.089 \pm 0.030$ (Crawfordsville), $0.178 \pm 0.040$ (Kanawha), and $0.133 \pm 0.036$ (Sutherland).
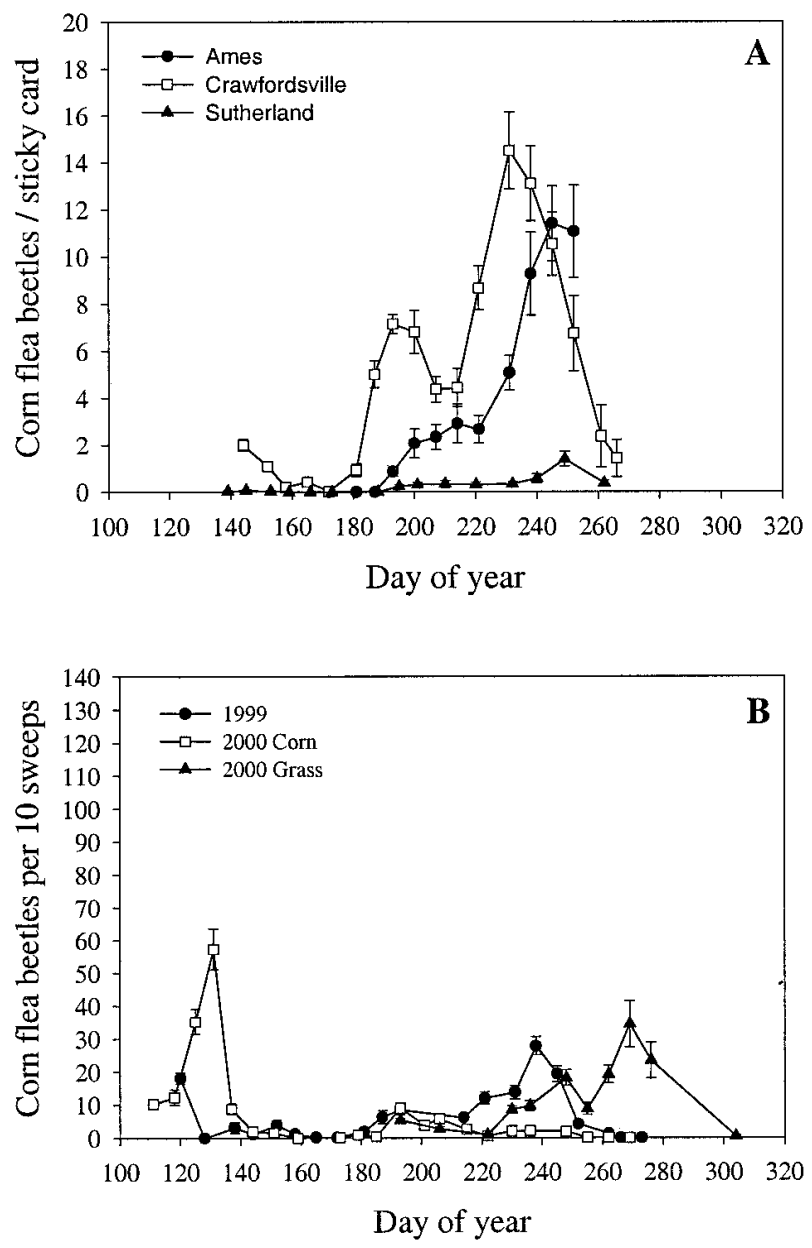

Fig. 3. A, Corn flea beetles per sticky card in 1999 at Ames, Crawfordsville, and Sutherland. B, Corn flea beetles per 10 sweeps at Crawfordsville in 1999 and 2000 . 


\section{DISCUSSION}

Risk assessment for Stewart's disease involves the analysis of four risk factors. These include (i) the prevalence of Stewart's disease the preceding season, (ii) using the mean monthly winter temperatures (December, January, and February) as a predictor of beetle survival, (iii) quantifying the population dynamics of the corn flea beetle vector, and (iv) quantifying the population dynamics of corn flea beetles infested with P. stewartii. By improving and quantifying our knowledge of all four risk factors, we have been able to improve our management recommendation for seed corn producers and sweet corn growers by advising them of the seasonal and site-specific risk potential for Stewart's disease, as well as providing information concerning the need for and timing of foliar insecticides to reduce corn flea beetle populations.

Using GIS to create site-specific prediction maps has provided a new tool to characterize and identify high-risk areas for Stewart's disease within Iowa. Such maps illustrate to producers the need to closely monitor their fields for corn flea beetle activity during high risk seasons and that they may need to deploy appropriate management tactics such as insecticide seed treatments to reduce corn flea beetle feeding early in the spring. Also, the prediction maps can provide important knowledge for producers to help them reduce the risk of Stewart's disease by choosing locations where disease risk is low. Thus, if producers choose to plant seed corn in a high-risk area, insecticide seed treatments would be highly recommended to reduce corn flea beetle feeding and pathogen transmission. Moreover, based upon the temporal patterns of corn flea beetle population dynamics, planting date could be modified to avoid early populations of corn flea beetles, thus lowering the risk for the wilt phase of Stewart's disease.

Prior to our study, there was no basis to make spray recommendations for corn flea beetles middle to late in the corn-growing season in Iowa. For example, corn flea beetle populations may be avoided by delaying planting until after peak corn flea beetle populations have emerged. Improved knowledge concerning when the first and second generation of corn flea beetles will occur should greatly improve the timing and efficacy of foliar-applied insecticides during the season to reduce corn flea beetle feeding (and transmission) on corn plants middle to late in the growing season. For example, we determined that there is a period ranging from 2 to 4 weeks in June in which corn flea beetle populations are not found, thus applying insecticides during this period would provide no economic benefit. Our research also has shown that there may be an economic advantage in applying foliar insecticides to control the first and second corn flea beetle generation in order to reduce the probability that Stewart's disease will be determined during seed corn inspections that occur throughout the month of August. Thus, we believe that foliar-applied insecticides may be economically beneficial when applied during the active first generation phase of corn flea beetles.

The ability to determine the proportion of $P$. stewartii-infested corn flea beetles is important from a management standpoint because it provides important quantitative information regarding the amount of inoculum present in and around cornfields. Corn flea beetle populations early in the season may be reduced by spraying grass borders or by applying insecticide seed treatments to coincide with high-risk years and locations. Combined with low disease risk site selection, altering the date of planting to avoid the overwintering generation of corn flea beetles, the use of insecticide seed treatments, and the use of well-timed foliar spray recommendations, these tactics should greatly improve the management of Stewart's disease.

\section{ACKNOWLEDGMENTS}

We thank Pioneer Hi-Bred, Novartis (Syngenta), DeKalb (Monsanto), and GARST Seeds, as well as the Iowa State University Center for Advanced Technology Development for financial support of this research project. Journal paper J-19516 of the Iowa Agriculture and Home Economics Experiment Station, Ames, Iowa, Project 3394, and supported by Hatch and State of Iowa funds.

\section{LITERATURE CITED}

1. Adams, R. G., and Los, L. M. 1986. Monitoring adult corn flea beetle (Coleoptera: Chrysomelidae) in sweet corn fields with color sticky traps. Environ. Entomol. 15:867-873.

2. Elliot, C., and Poos, F. W. 1940. Seasonal development, insect vectors, and host range of bacterial wilt of sweet corn. J. Agric. Res. 60:645-686.

3. Lamka, G. L., Hill, J. H., McGee, D. C., and Braun, E. J. 1991. Development of an immunosorbent assay for seedborne Erwinia stewartii in corn seeds. Phytopathology 81:839-846.

4. Nutter, F. W., Jr., Rubsam, R. R., Taylor, S. E., Harri, J. A., and Esker, P. D. Use of geospatially-referenced disease and weather data to improve site-specific forecasts for Stewart's disease of corn in the U.S. corn belt. Comput. Electron. Agric. In press.

5. Nutter, F. W., Jr., Wegulo, S. N., Rubsam, R. R., Taylor, S. E., and Harri, J. A. 1998. Use of geospatially reference disease and weather data to improve site-specific forecasts for Stewart's disease of corn. (Abstr.) Phytopathology 88(suppl.):S68.

6. Pataky, J. K. 1985. Relationships among reactions of sweet corn hybrids to Goss's wilt, Stewart's bacterial wilt, and northern corn leaf blight. Plant Dis. 69:845-848.

7. Rand, F. V., and Cash, L. C. 1933. Bacterial wilt of corn. USDA Tech. Bull. 362:1-22.

8. Roberts, A. L. 1955. Bacterial wilt and Stewart's leaf blight of corn. U.S. Dep. Agric. Farmers Bull. 2092:13.

9. Steel, R. G. D., Torrie, J. H., and Dickey, D. A. 1997. Principles and Procedures of Statistics, a Biometrical Approach. 3rd ed. McGraw-Hill Publishing Co., New York.

10. Suparyono and Pataky, J. K. 1989. Influence of host resistance and growth stage at the time of inoculation on Stewart's wilt and Goss' wilt development and sweet corn hybrid yield. Plant Dis. 73:339-345. 